\title{
低負荷型ライフスタイルによる住宅のエネルギー消費量削減の可能性 ENERGY SAVING POTENTIAL OF LOW-IMPACT LIFE STYLE IN RESIDENTIAL BUILDINGS
}

\author{
湯 淺 和 博*1, 劉 正 賢*2, 吉 野 博*3, 長谷川 兼一 ${ }^{* 4}$ \\ Kazuhiro YUASA, Junghyun YOO, Hiroshi YOSHINO \\ and Kenichi HASEGAWA
}

\begin{abstract}
The purpose of this study is to make clear the energy saving potential of low-impact life style through the measurement of energy consumptioin in residential buildings. The actions for low-impact life style are "to control the heat loss or heat gain by using curtains and blinds", "to set PC at saving energy mode" and so on. The results are as follows.

(1) In one-person households, energy saving of 3.6-44.6\% were achieved. Low-impact life style of air conditioning,

lighting and information home appliances were effectively practiced.

(2) In family households, $50-70 \%$ of whole subjects achieved $0.9-14.1 \%$ energy saving.
\end{abstract}

Keywords: Energy Consumption, Residential Building, Low-Impact Life Style, Measurement エネルギー消費量, 住宅, 低負荷型ライフスタイル，実測

1.はじめに

近年、生活における利便性・快適性の追求、保有家電機器の多様 化等に伴い、民生家庭部門のエネルギー消費量は増大傾向にある。 2006 年度のエネルギー消費量は 1990 年比で 1.3 倍程度となってお り、今後もその増大が懸念されている ${ }^{1)} 。 2005$ 年 2 月の京都議定書 の発効は、既存の産業・運輸部門における対策に加えて、民生家庭 部門における温室効果ガス排出量の抑制に向けた対策を重要な施策 として位置付けている。省エネルギー法の強化による断熱性能の向 上、トップランナー方式の導入や技術革新等と云ったハード面での 対策が実施されている一方で、日常生活における省エネルギーを意 識した住まい方への移行等のソフト面の対策も重要と考えられる。 現実的には、居住者による快適性の要求レベルの向上を抑制するこ とは困難であるが、まずは居住者自身にとつて無理のない範囲で節 約志向の意を含めた住まい方へ移行することが第一段階と思われる。

住宅のエネルギー消費は、住宅ごとのばらつきが大きいが、気候・ 立地条件・構造・住まい方等の多くの要因が影響すること等、これ までに数多くの既往研究が報告されている。最近では、日本建築学 会において住宅内のエネルギー消費量に関する全国的調査が実施さ れ、結果の一部は、例えば文献2 2 7報告されている。また、住宅 における省エネルギー手法に関連して、建物性能の向上に関する研 究としては、例えば、赤林ら ${ }^{81}$ 、長谷川ら ${ }^{91}$ の研究があり、断熱・気 密化と暖冷房負荷の低減等について報告されている。
一方、ライフスタイルに関わる研究として、森ら ${ }^{10)}$ は居住者の節 約行為とエネルギー消費量の関係を、前ら $\left.{ }^{11}\right)$ は集合住宅の居住者の 生活時間に関するアンケート調査の分析を、澤島ら ${ }^{12)}$ は居住者の夏 期の防暑行為の実施実態と意識・価値観の関係を、丹羽ら ${ }^{13)}$ は暖房 用エネルギー消費量について居住者意識と暖房の仕方からみた検討 を、大和ら ${ }^{14)}$ は夏期・冬期のエネルギー消費増加量に影響を及ぼす 居住者の意識・住まい方の違いを、平松ら ${ }^{15)}$ は家族成長を考慮した エネルギーシステムの評価を、水谷ら ${ }^{16)}$ は用途別エネルギー消費と 住まい方の実態を、小林ら ${ }^{17)}$ は空調における補助的な冷暖房行為の 効果を報告している。しかしながら、ライフスタイルの改善による 住宅全体のエネルギー消費量の削減可能性を実測的に把握した研究 は見られない。

本研究では、住宅内のエネルギー消費量が削隇されるような居住 者の生活行動を低負荷型ライフスタイルと定義し、これを地球温暖 化防止対策の一つとして捉えた場合に、ぞの程度の削隇効果が期待 できるかを、エネルギー消費量の実測を通じて明らかにすることを 目的としている。具体的には、関東地域の単身世帯と、日本建築学 会の住宅内のエネルギー消費に関する調査にご協力頂いた家族世帯 の一部に、低負荷型ライフスタイルを一定期間実施して頂き、平常 時を含めたエネルギー消費量の実測結果の分析を行っている。なお、 既報 ${ }^{18)}$ において、低負荷型ライフスタイルの省エネルギー効果を、 標準型住宅モデルを用いた数值計算で検討した結果を報告している。
*1 東京工業大学大学院理工学研究科建築学専攻 准教授.工博

*2 東京工業大学大学院理工学研究科建築学専攻 大学院生·工修

*3 東北大学大学院工学研究科 教授. 工博

*4 秋田県立大学システム科学技術学部 准教授. 工博
Assoc. Prof., Department of Architecture and Building Engineering, Tokyo Institute of Technology, Dr. Eng.

Graduate Student, Department of Architecture and Building Engineering, Tokyo Institute of Technology, M. Eng.

Prof., Graduate School of Engineering, Tohoku University, Dr. Eng.

Assoc. Prof., Faculty of System Science and Technology, Akita Prefectural University, Dr. Eng. 
表 1 被験者に示した低負荷型ライフスタイルと実行度の調査結果

\begin{tabular}{|c|c|c|c|c|}
\hline \multirow{2}{*}{$\begin{array}{l}\text { 用途 } \\
\text { 区分 }\end{array}$} & \multirow{2}{*}{ 機器名称等 } & \multirow{2}{*}{ 低負荷型ライフスタイル } & \multicolumn{2}{|c|}{ 平均実行度 } \\
\hline & & & 単身 & 家族 \\
\hline \multirow{18}{*}{ 空調 } & \multirow{8}{*}{ エアコン } & 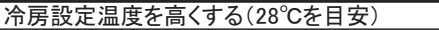 & 4.9 & 3.2 \\
\hline & & 暖房設定温度を低くする(20Cを目安） & 4.9 & 3.7 \\
\hline & & 使用時間を短くする & 4.6 & 3.2 \\
\hline & & こまめにエアフィルターを清掃する & 1.8 & 2.7 \\
\hline & & カーテン・ブラインドで熱の出入りを調節する & 3.0 & 3.3 \\
\hline & & 扇風機を併用する & 3.3 & 3.2 \\
\hline & & ドア·空の開閉時間を短くする & 3.2 & 3.9 \\
\hline & & 家族が同じ部屋で団欒する & & 3.2 \\
\hline & \multirow{4}{*}{$\begin{array}{c}\text { ガス・石油 } \\
\text { ファン } \\
\text { ヒーター }\end{array}$} & 設定温度を低くする(20Cを目安) & & 3.3 \\
\hline & & 使用時間を短くする & & 2.0 \\
\hline & & 外出·就寝時は早めにオフにする & & 1.7 \\
\hline & & こまめにエアフィルターを清掃する & & 2.3 \\
\hline & \multirow{2}{*}{$\begin{array}{c}\text { 電気 } \\
\text { カーペット } \\
\end{array}$} & 設定温度を調節する & & 2.3 \\
\hline & & エアコンとの併用時は低温にする & & 1.3 \\
\hline & 扇風機 & 風量を調節する & 1.0 & 3.7 \\
\hline & \multirow{2}{*}{ こたつ } & 設定温度を低くする & 1.0 & 2.8 \\
\hline & & 座布団や上掛けと併用する & 1.0 & 2.8 \\
\hline & 全般 & 非使用時にはコンセントを抜く & 4.6 & 2.4 \\
\hline \multirow{21}{*}{ 厨房 } & \multirow{6}{*}{ 冷蔵庫 } & 季節に合わせて設定温度を調節する & 2.5 & 2.1 \\
\hline & & 熱い物は常温で泠やしてから入れる & 3.1 & 4.2 \\
\hline & & 開閉回数を少なくする & 4.2 & 3.2 \\
\hline & & 開閉時間を短くする & 4.0 & 3.3 \\
\hline & & 物を詰め込み過ぎないようにする & 2.7 & 3.4 \\
\hline & & 放熱面に物を載せないようにする & 2.1 & 3.1 \\
\hline & \multirow{5}{*}{ 調理 } & 下ごしらえは電子レンジを使用する & 1.5 & 2.6 \\
\hline & & 鍋底の水滴を拭き取ってから火にかける & 3.0 & 4.3 \\
\hline & & 鍋は底の面積が大きい物を使用する & 1.2 & 3.4 \\
\hline & & 落し蓋を使用する & 1.0 & 2.7 \\
\hline & & 段取り良く調理する & 3.0 & 3.3 \\
\hline & \multirow{3}{*}{ 電気ポット } & 保温時間を短くする & & 1.6 \\
\hline & & 低温で保温する & 1.0 & 1.7 \\
\hline & & 使用しない(ガスコンロで湯を沸かす) & 1.6 & 3.3 \\
\hline & \multirow{2}{*}{ 炊飯器 } & 保温時間を短くする & 3.6 & 3.6 \\
\hline & & 保温しない & & 2.7 \\
\hline & \multirow{3}{*}{$\begin{array}{c}\text { 食器洗い } \\
\text { 乾燥機 }\end{array}$} & まとめて洗う & & 3.6 \\
\hline & & 設定温度を調節する & & 1.8 \\
\hline & & 標準(節約)コースで洗う & & 4.1 \\
\hline & 電子レンジ & 泠凍食品は自然解凍する & & 2.7 \\
\hline & 全般 & 非使用時にはコンセントを抜く & & 3.0 \\
\hline
\end{tabular}

2. 住宅における低負荷型ライフスタイル

本研究では、まず、居住者に低負荷型ライフスタイルを提示し、実 行可能な項目を自発的に選択させた。その後、低負荷型ライフス夕 イルのエネルギー消費量を 1 週間実測して、平常時と比較検討した。

居住者に示した低負荷型ライフスタイルを表 1 に示す。2003 年以 前におけるエネルギー関連企業・省庁等の出版物や HP 等を参考にし てまとめたものであり、空調・㕌房・給湯・照明・娛楽情報・家事 衛生に関連する機器ごとの分類として全 77 項目である。なお、同表 は後述の単身世帯・家族世帯の実測における低負荷型ライフスタイ ルの実行度の調査結果を含めたものとなっている。実行度は、選択 項目の 1 週間の実施状況を居住者自身が 5 段階で評価した值である。

3．低負荷型ライフスタイルの省エネルギー効果

3. 1 関東地域の単身世帯における実測

(1) 実測概要

2003 年度の夏期 ・ 中間期 (秋期) - 冬期に、関東地域の単身世帯 を対象として実測した。表 2 に実測調査の概要を示す。被験者は東 京都または神奈川県に立地する集合住宅に住む 20 代の学生 4 名と社 会人 2 名である。一世帯につき $7 \sim 16$ 点の家電機器の電力消費量と、 住宅全体の電力・ガス消費量を測定している。ただし、照明の電力 消費量については、直接に測定することが困難であったため、照明 器具の近傍に温度ロガーを取り付け、温度上昇から使用時間を測定 して推定した。なお、測定器数の関係上、複数の家電機器をまとめ て測定することにより、多くの家電機器の電力消費量を把握するこ

\begin{tabular}{|c|c|c|c|c|}
\hline \multirow{2}{*}{ 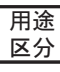 } & \multirow{2}{*}{ 機器名称等 } & \multirow{2}{*}{ 低負荷型ライフスタイル } & \multicolumn{2}{|c|}{ 平均実行度 } \\
\hline & & & 単身 & 家族 \\
\hline \multirow{13}{*}{ 給湯 } & \multirow{4}{*}{ 風呂 } & 家族が時間を合わせて続けて入浴する & & $\begin{array}{l}2.9 \\
28\end{array}$ \\
\hline & & $\begin{array}{l}\text { 人溶者が多い場合には湯船で人浴する } \\
\text { シャワ時間を短くする }\end{array}$ & 2.1 & $\begin{array}{l}2.8 \\
3.1\end{array}$ \\
\hline & & 入浴後はふたを閉じる & & 4.5 \\
\hline & & 湯張りの量を少なめに設定する & 1.1 & 3.1 \\
\hline & \multirow{6}{*}{ 炊事 } & ガス給湯器は非使用時に種火を消す & & 3.0 \\
\hline & & 湯を沸かす時は中火で沸かす & 2.0 & 2.7 \\
\hline & & 給湯器の湯をコンロで沸騰させる & 1.3 & 1.5 \\
\hline & & 食器洗いの際の湯温を低くする & 2.8 & 3.6 \\
\hline & & 洗い物はため洗いをする & & 2.9 \\
\hline & & 手洗いでなく食器洗い乾燥機を使用する & & 3.1 \\
\hline & \multirow{3}{*}{ 洗面 } & 給湯の使用時間を短くする & & 3.4 \\
\hline & & 給湯の設定温度を低くする & 2.1 & 3.3 \\
\hline & & 温水を使用しない & 2.6 & 2.9 \\
\hline \multirow{3}{*}{ 照明 } & & 無駄な明かりをつけない & 4.9 & 4.1 \\
\hline & \multirow[t]{2}{*}{ 照明 } & 点灯時間を短くする & & 3.3 \\
\hline & & 家族が同じ部屋で団奱する & & 3.1 \\
\hline \multirow{9}{*}{ 娛楽 } & \multirow{4}{*}{ テレビ } & 菲使用時は主電源を切る & 4.3 & 3.2 \\
\hline & & 使用時間を短くする & & 2.5 \\
\hline & & 画面を明るくしすぎないようにする & 1.6 & 3.0 \\
\hline & & 音量を上げすぎないようにする & 2.9 & 3.4 \\
\hline & ビデオ & 非使用時は主電源を切る & 3.9 & 3.4 \\
\hline & $\mathrm{CD} / \mathrm{MD}$ & 非使用時は主電源を切る & 4.6 & 3.7 \\
\hline & パソコン & 省エネモードにする & 1.8 & 3.2 \\
\hline & 携帯電話 & 茺電したままにしない & 2.4 & 3.5 \\
\hline & 全般 & 韭使用時にはコンセントを抜く & 4.0 & 2.6 \\
\hline \multirow{12}{*}{ 家事 } & \multirow{3}{*}{ 洗濯機 } & 風呂の温水を洗濯に使用する & 1.0 & 3.5 \\
\hline & & まとめ洗いをする & 4.1 & 4.4 \\
\hline & & 軽い污れはスピードコースを使用する & 1.7 & 2.4 \\
\hline & \multirow{4}{*}{ 掃除機 } & 先に部屋を片付け、使用時間を短くする & 2.7 & 4.1 \\
\hline & & 吸引力を調節する & 1.0 & 3.5 \\
\hline & & こまめにフィルタ一を掃除する & & 2.9 \\
\hline & & 集塵パツクを適宜取り替える & 2.0 & 3.6 \\
\hline & \multirow{3}{*}{$\begin{array}{c}\text { 温水洗浄 } \\
\text { 便座 }\end{array}$} & 非使用時はふたを閉じる & & 3.5 \\
\hline & & 季節に合わせて設定温度を調節する & & 3.8 \\
\hline & & 外出時はオフにする & & 2.0 \\
\hline & ドライヤー & 風量を調節する & 1.2 & 2.5 \\
\hline & T. & 髮をよく拭いてから使用する & & 3.3 \\
\hline
\end{tabular}

実行度：1ー実行しなかった 2ーわずかに実行した $3 \rightarrow$ 時々実行した $4 \rightarrow$

表 2 単身世帯の実測調査概要

\begin{tabular}{|c|c|c|c|c|c|c|}
\hline 期間 & \multicolumn{6}{|c|}{ 2003年度の夏期・中間期·冬期に2週間（省エネ週間＋通常週間） } \\
\hline \multirow{7}{*}{ 内容 } & \multirow{3}{*}{ 電力 } & 総消費量 & \multicolumn{4}{|c|}{ 分電盤用測定器による1分毎の自動計測(1点) } \\
\hline & & 家電機器 & \multicolumn{4}{|c|}{ 家電機器用測定器による1分毎の自動計測 (7 16点) } \\
\hline & & 照明 & \multicolumn{4}{|c|}{ 小型温度ロガー(10分毎の計測)の温度変化に基づく推定 } \\
\hline & & & \multicolumn{4}{|c|}{ 被験者によるメーターの読み取り } \\
\hline & 加 & 䄈洞貫重 & \multicolumn{4}{|c|}{ 小型温度ロガー(10分毎の計測)の温度変化に基づく推定 } \\
\hline & 環境 & 温湿度 & \multicolumn{4}{|c|}{ 室内外の温湿度ロガーによる10分毎の計測 } \\
\hline & 実行度 & 低負荷型= & \multicolumn{4}{|c|}{ ジライフスタイルの実行度を5段階評価 (1:実行せず〜5:常に実行) } \\
\hline \multirow{7}{*}{ 被験者 } & & 性別 & 職業 & 住所 & 延床面積 & 構造 \\
\hline & A & 女性 (22) & 公務員 & 神奈川県横浜市 & $19.0 \mathrm{~m}^{2}$ & 木造 \\
\hline & B & 男性(25) & 学生 & 神奈川県横浜市 & $33.1 \mathrm{~m}^{2}$ & 木造 \\
\hline & $\mathrm{c}$ & 男性 (22) & 学生 & 東京都大田区 & $15.2 \mathrm{~m}^{2}$ & 木造 \\
\hline & D & 男性 (27) & 会社員 & 神奈川県横浜市 & $18.0 \mathrm{~m}^{2}$ & 木造 \\
\hline & $\mathrm{E}$ & 男性 (24) & 学生 & 東京都世田谷区 & $42.7 \mathrm{~m}^{2}$ & 鉄筋コンクリート造 \\
\hline & $\mathrm{F}$ & 男性(23) & 学生 & 神奈川県横浜市 & $21.2 \mathrm{~m}^{2}$ & 軽量鉄骨造 \\
\hline
\end{tabular}

表 3 測定期間と平均外気温度

\begin{tabular}{|c|c|c|c|c|c|c|c|c|c|}
\hline \multirow{2}{*}{\multicolumn{2}{|c|}{ 区分 }} & \multicolumn{2}{|c|}{ 夏期(冷房期) } & \multicolumn{2}{|l|}{ 中間期 } & \multicolumn{2}{|c|}{ 冬期(暖房期) } & \multicolumn{2}{|c|}{ 空調時間 } \\
\hline & & 実測期間 & 気温 & 実測期間 & 気温 & 実測期間 & 気温 & 冷房 & 暖房 \\
\hline \multirow{2}{*}{ A } & 省エネ & $8 / 18 \sim 8 / 22$ & 30.0 & $10 / 27 \sim 10 / 31$ & 17.7 & $12 / 15 \sim 12 / 19$ & 8.3 & 10 & 29 \\
\hline & 通常 & $8 / 25 \sim 8 / 29$ & 31.5 & $11 / 4 \sim 11 / 7$ & 17.3 & $12 / 22 \sim 12 / 26$ & 8.8 & 3 & 33 \\
\hline \multirow{2}{*}{ B } & 省エネ & $8 / 4 \sim 8 / 8$ & 30.0 & $10 / 14 \sim 10 / 17$ & 16.5 & $12 / 1 \sim 12 / 5$ & 11.2 & 429 & 7 \\
\hline & 通常 & $8 / 11 \sim 8 / 15$ & 26.0 & $10 / 20 \sim 10 / 24$ & 16.4 & $12 / 8 \sim 12 / 12$ & 8.3 & 804 & 612 \\
\hline \multirow{2}{*}{ C } & 省エネ & $8 / 4 \sim 8 / 8$ & 29.1 & $10 / 27 \sim 10 / 31$ & 17.6 & $1 / 5 \sim 1 / 9$ & 7.0 & 422 & 119 \\
\hline & 通常 & $8 / 11 \sim 8 / 15$ & 24.8 & $11 / 4 \sim 11 / 7$ & 18.0 & $1 / 12 \sim 1 / 16$ & 6.2 & 450 & 264 \\
\hline \multirow{2}{*}{ D } & 省エネ & $8 / 18 \sim 8 / 22$ & 27.2 & $10 / 14 \sim 10 / 17$ & 16.1 & $12 / 1 \sim 12 / 5$ & 11.6 & 372 & 106 \\
\hline & 通常 & $8 / 25 \sim 8 / 29$ & 28.4 & $10 / 20 \sim 10 / 24$ & 16.4 & $12 / 8 \sim 12 / 12$ & 8.5 & 295 & 303 \\
\hline \multirow{2}{*}{$E$} & 省エネ & $7 / 22 \sim 7 / 25$ & 25.1 & $9 / 29 \sim 10 / 3$ & 23.6 & $1 / 5 \sim 1 / 9$ & 14.1 & 0 & 774 \\
\hline & 通常 & $7 / 28 \sim 8 / 1$ & 24.1 & $10 / 6 \sim 10 / 10$ & 21.3 & $1 / 12 \sim 1 / 16$ & 12.6 & 0 & 891 \\
\hline \multirow{2}{*}{$\mathrm{F}$} & 省エネ & $7 / 22 \sim 7 / 25$ & 22.5 & $9 / 29 \sim 10 / 3$ & 20.1 & \multirow{2}{*}{\multicolumn{2}{|c|}{ 欠測 }} & 0 & 欠欠測 \\
\hline & 通常 & $7 / 28 \sim 8 / 1$ & 24.5 & $10 / 6 \sim 10 / 10$ & 17.5 & & & 0 & \\
\hline
\end{tabular}

表中の気温は実測期間に゙おける平均外気温度 $\left({ }^{\circ} \mathrm{C}\right) 、$ 空調時間はエアコン使用時間(分/日)を表す。 
ととした。ガスについては照明と同様に、ガス使用箇所および近傍 の温度上昇から推定した使用時間と、被験者自身によるガスメー ターの読み取り值に基づき消費量を推定した。測定期間は 2 週間と し、1 週目は低負荷型ライフスタイルを実行した省エネルギー週間、 2 週目は通常通りの生活を行う通常週間とした。

表 3 に被験者別・季節別の平均外気温度を示す。測定器数の都合 上、全被験者の実測に 6 週間を要しており、例えば夏期において 22.5 $\sim 31.5^{\circ} \mathrm{C}$ 等の差を生じているが、被験者間の絶対的な比較を行うこ とは目的としていないので、特に補正は行っていない。解析に際し ては、エネルギー消費量・気象条件・在宅時間等を考慮し、平均的 な 3 日間を省エネルギー週間と通常週間からそれぞれ抽出した。

表 4 に被験者の保有機器と待機電力の測定結果を示す。全被験者 に共通する保有機器はエアコン・テレビ・冷蔵庫・洗濯機であり、そ の他は被験者により大きく異なる。また、各被験者の機器購入時期 が異なるため、同一機器でも待機電力に差が認められる。各被験者 には自身の保有機器および表 1 中で関連する低負荷型ライフス夕イ ルを確認してもらった上で 2 週間の実測を開始している。

(2) 実測結果

実測結果の一例として、電力消費量の時刻変動を図 1 に示す。こ こでは、被験者 D を対象に、中間期において省エネルギー週間と通 常週間で在宅時間が類似した 1 日を抽出し、同一時刻に対する重秝 書きで示している。就寝時または不在時と考えられる $2 \sim 7$ 時や 8 24 時においては、太線で示される省エネルギー週間の值が明らかに 小さくなっており、低負荷型ライフスタイルが実行されたことが確 認された。

図 2 に全被験者のエネルギー消費量を、通常週間と省エネルギー 週間で比較した結果を示す。各期の棒グラフ上部に記した数值は、 通常週間のエネルギー消費量に対する省エネルギー週間の削減量の 割合 (省エネルギー率) である。通常週間におけるエネルギー消費 量の絶対値は $23.1 \mathrm{MJ} /$ 日（被験者 $\mathrm{F}$ ・中間期）～66.4 M J/日（被験 者 B ・ 冬期）と個人差および季節による相違が大きいが、全被験者 が省エネルギー週間にエネルギー消費量を削隇する結果となった。 省エネルギー率としては、3.6\%（被験者 $\mathrm{E} \cdot$ 中間期）～4 4.6\%（被 験者 C・冬期）となっており、延べ 17 期中の 13 期で $10 \%$ を超えて いる。エネルギー消費の削減量は、夏期で $3.7 \mathrm{MJ} /$ 日（被験者 F ） 19.4 (被験者 C)、中間期で $1.2 \mathrm{MJ} /$ 日（被験者 B ）～7.9MJ/日（被 験者 $\mathrm{A}$ )、冬期で $3.2 \mathrm{MJ} /$ 日（被験者 $\mathrm{A} ） \sim 30.0 \mathrm{MJ} /$ 日（被験者 $\mathrm{C}$ ) と、空調換気のエネルギー消費が生じる夏期・冬期で大きい。
表 4 被験者（単身世帯）の保有機器と待機電力

\begin{tabular}{|c|c|c|c|c|c|c|c|}
\hline \multirow{2}{*}{ 区分 } & \multirow{2}{*}{ 機器名称 } & \multicolumn{6}{|c|}{ 被験者 } \\
\hline & & A & B & $\mathrm{C}$ & $\mathrm{D}$ & $E$ & $\mathrm{~F}$ \\
\hline \multirow{4}{*}{ 空調 } & エアコン & 2.04 & 0.93 & 0.73 & 2.46 & 0.26 & 1.56 \\
\hline & 扇風機 & & $\mathrm{O}$ & & & & \\
\hline & こたつ & & 0 & & 0 & & \\
\hline & 電気ヒーーター & & & & 0 & & \\
\hline \multirow{18}{*}{$\begin{array}{l}\text { 情報 } \\
\text { 娛楽 }\end{array}$} & テレビ & 1.30 & 0.01 & 0 & 0.51 & 4.74 & 0 \\
\hline & ビデオデッキ & 0.52 & 0 & 4.80 & 0 & 0.23 & \\
\hline & DVDプレイヤー & & & & & 1.91 & \\
\hline & スピーカー & $\mathrm{O}$ & & & 1.13 & & \\
\hline & ゲーム機(1) & 0 & 0 & & 0 & & \\
\hline & ゲーム機(2) & & 0 & & & & \\
\hline & コンポ & 10.75 & 0 & & & 1.39 & \\
\hline & ラジカセ & & & 5.68 & 9.44 & & 3.43 \\
\hline & パソコン本体 & 0 & 0 & 9.75 & 3.42 & & \\
\hline & パソコンモニタ & 0 & 0 & 0 & 0 & & \\
\hline & プリンタ & & 0 & & $\mathrm{O}$ & & \\
\hline & ADSLモデム & 0 & 0 & & 0 & & \\
\hline & FDD & & 0 & & & & \\
\hline & ハブ & & 0 & & & & \\
\hline & 電気スタンド & & 0 & & 0 & 0 & \\
\hline & キーボード & & & 0 & & & \\
\hline & 電話機 & 0 & $\mathrm{O}$ & & 0 & 0 & \\
\hline & 携帯電話充電器 & 0 & 0 & & 0.11 & 0 & 0 \\
\hline \multirow{13}{*}{$\begin{array}{l}\text { 家事 } \\
\text { 衛生 }\end{array}$} & 冷蔵庫 & $\mathrm{O}$ & $\mathrm{O}$ & $\mathrm{O}$ & $\mathrm{O}$ & 0 & $\mathrm{O}$ \\
\hline & 電子レンジ & 0 & 1.20 & 0 & 0 & 4.47 & \\
\hline & 炊飯器 & 0 & 0 & 0 & 0 & 0 & \\
\hline & 電気ポツト & 0 & 0 & 0 & & & \\
\hline & トースター & & & & & 0 & \\
\hline & コーヒーミル & & & & & 0.75 & \\
\hline & 洗濯機 & 2.01 & 0.04 & 1.49 & 0 & 0.06 & 1.58 \\
\hline & 衣類乾燥機 & & 1.10 & & & & \\
\hline & 掃除機 & 0 & & & 0 & & \\
\hline & ドライヤー & & & $\mathrm{O}$ & $\mathrm{O}$ & & \\
\hline & シェーバー & & & 0 & 0 & & \\
\hline & コンタクト洗浄器 & & & & & $\mathrm{O}$ & \\
\hline & 電気コンロ & & & 0 & & & \\
\hline \multicolumn{2}{|c|}{ 待機電力の合計 $(W)$} & 16.62 & 3.28 & 22.45 & 17.07 & 13.81 & 6.57 \\
\hline
\end{tabular}

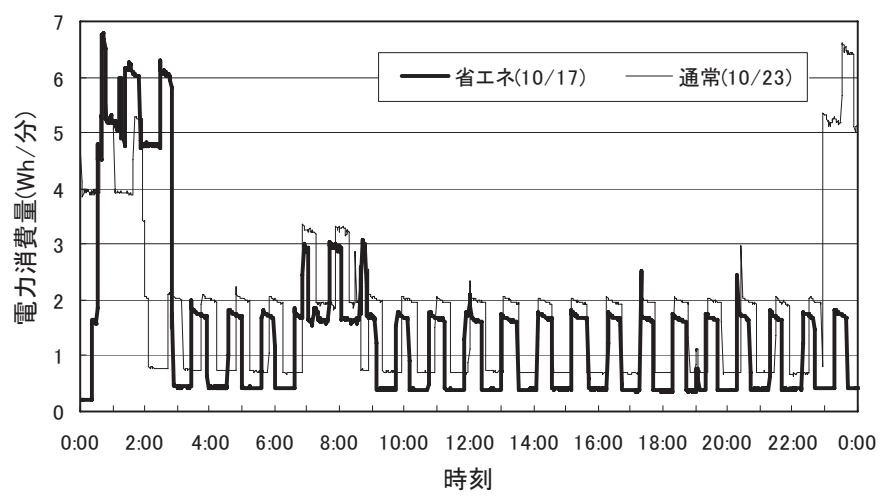

図 1 電力消費量の時刻変動例（被験者 D - 中間期）

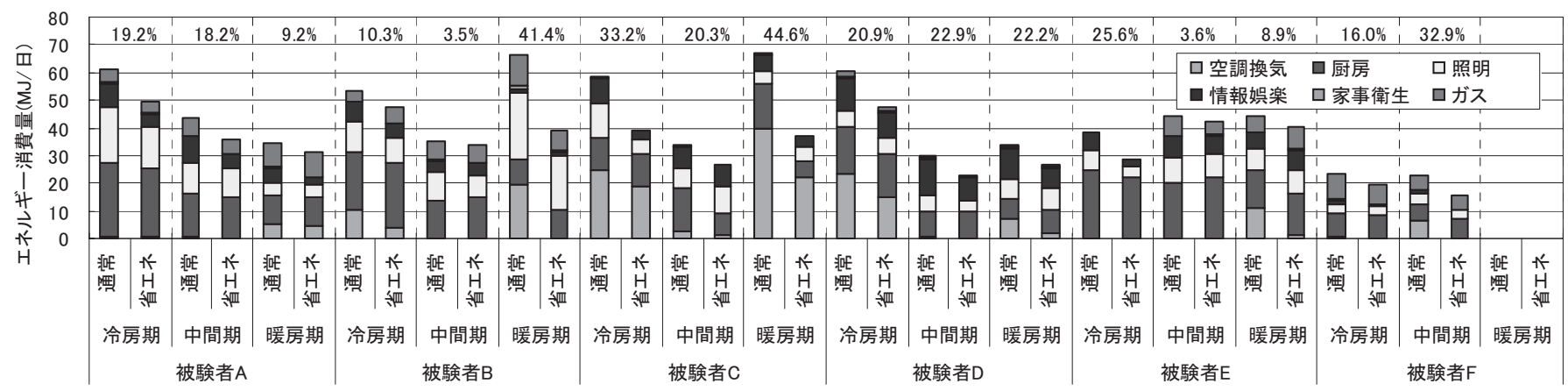

図 2 全エネルギー消費量の測定結果 


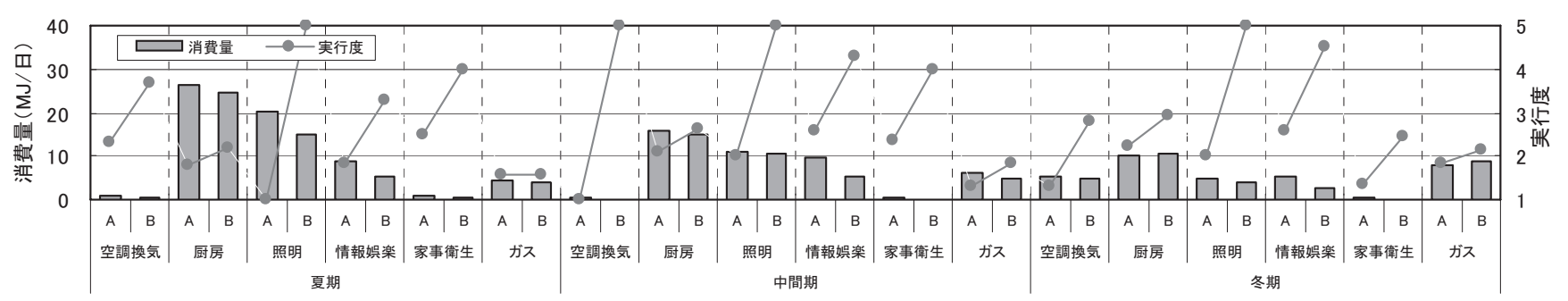

(1) 被験者 $\mathrm{A}$

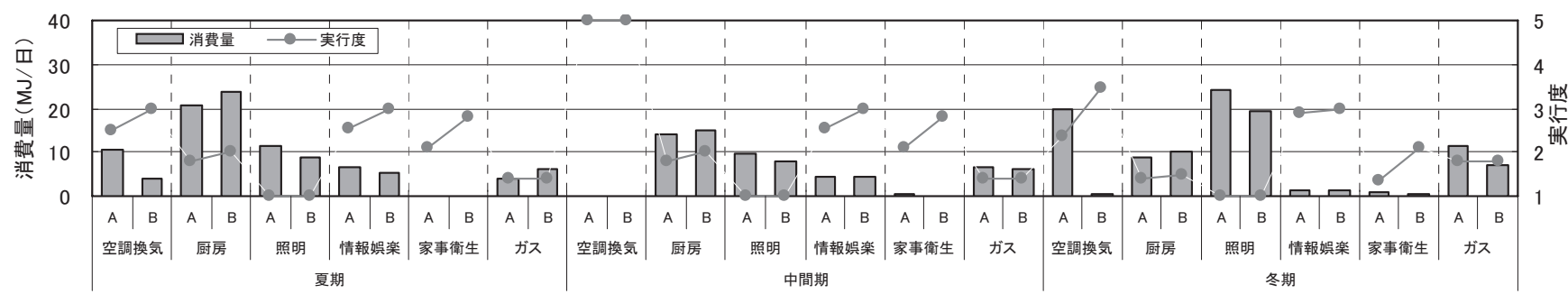

( 2 ）被験者 $\mathrm{B}$

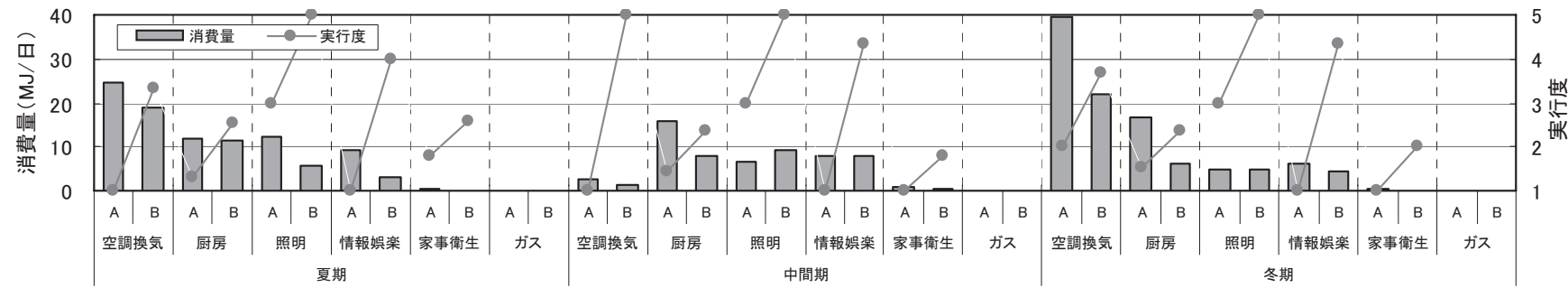

（3）被験者 $\mathrm{C}$

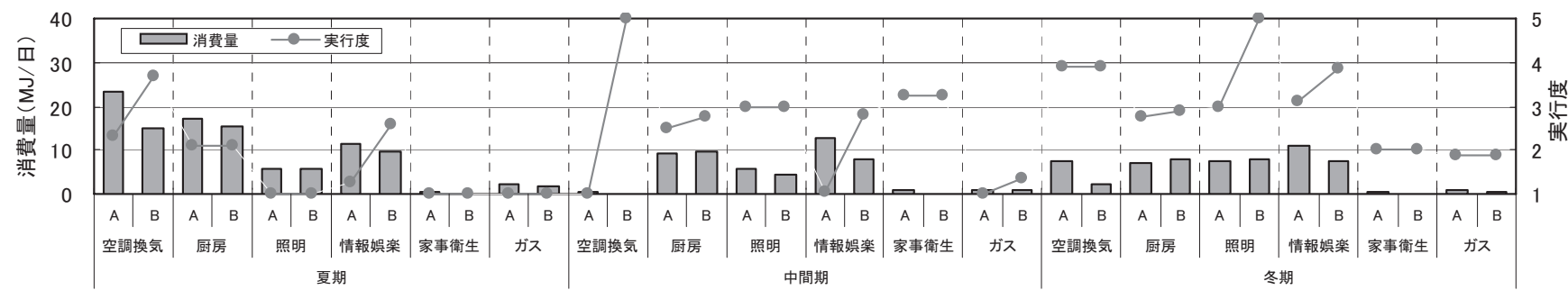

（4）被験者 D

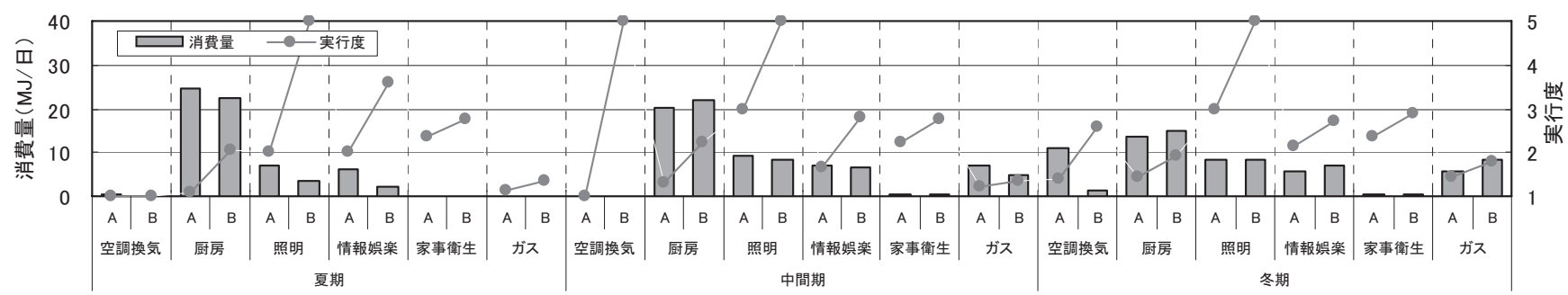

(5) 被験者 $\mathrm{E}$

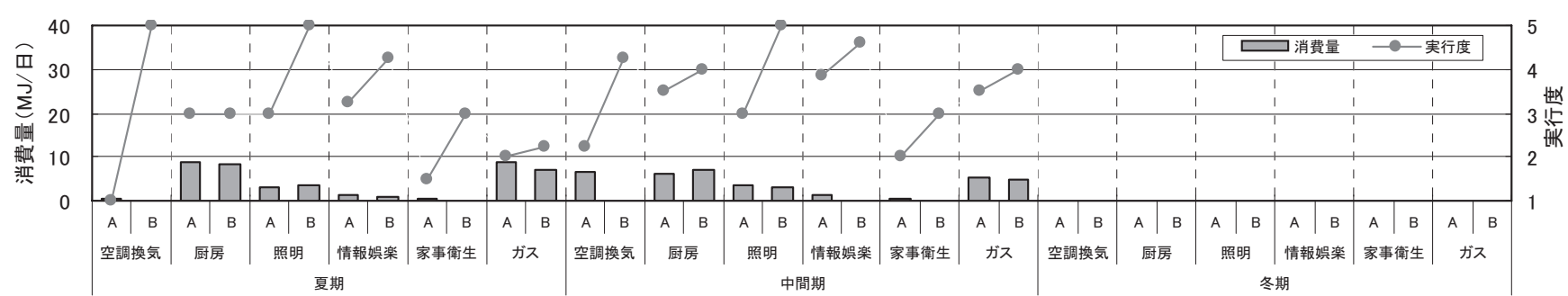

( 6 ）被験者 $\mathrm{F}$

A : 通常期間 B : 省エネ期間達成度 1 : 実行しない $2:$ わ゙かに 害行した $3:$ 時々害行した $4:$ かなり実行した $5:$ 常に害行した

図 3 単身世帯におけるエネルギー消費量と低負荷型ライフスタイルの実行度の対応 
図 3 は全被験者の用途区分別エネルギー消費量と低負荷型ライフ スタイルの実行度の対応をみたものである。実行度は、低負荷型ラ イフスタイルの各項目を表 1 の用途区分ごとに平均して示した。被

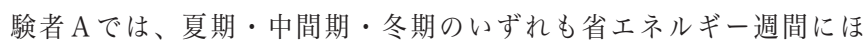
とんどの用途区分で実行度が高くなっており、特に空調換気・照明・ 情報娛楽・家事衛生では実行度が 1.0 以上高い。エネルギー削減量 は照明（夏期 $5.3 \mathrm{MJ} /$ 日）と情報娛楽（夏期 $3.5 \mathrm{MJ} /$ 日・中間期 $4.3 \mathrm{MJ} /$ 日・冬期 $2.3 \mathrm{MJ} /$ 日）で大きく、住宅全体のエネルギー削隇に寄与し ている。空調換気と家事衛生でも省エネルギーが達成されているが、 絶対量が小さい。被験者 Bでは、省エネルギー週間に実行度は高く なっているが、他の被験者と比較して通常週間との差は小さい。工 ネルギー削減量は空調換気（夏期 $6.5 \mathrm{MJ} /$ 日・冬期 $19.5 \mathrm{MJ} /$ 日）、照 明 (夏期 $2.8 \mathrm{MJ} /$ 日・中間期 $1.8 \mathrm{MJ} /$ 日・冬期 $4.6 \mathrm{MJ} /$ 日) 、ガス (冬 期 $4.3 \mathrm{MJ} /$ 日）で大きい。ただし、照明とガスの実行度は省エネルギー 週間で向上が無く、省エネルギー効果は低負荷型ライフスタイルに よるものとは言い切れない。

夏期・中間期・冬期のいずれも $20 \%$ を越える省エネルギーを達成 した被験者 Cの場合、全用途区分で省エネルギー週間に実行度が高 くなっており、エネルギー削隇量は空調換気（夏期 $5.5 \mathrm{MJ} /$ 日 ・冬期 $17.6 \mathrm{MJ} /$ 日）、厛房（中間期 $7.6 \mathrm{MJ} /$ 日 - 冬期 $10.6 \mathrm{MJ} /$ 日）、情報娱楽 （夏期 $6.3 \mathrm{MJ} /$ 日・冬期 $1.7 \mathrm{MJ} /$ 日）が大きい。被験者 $\mathrm{D}$ も夏期・中間 期・冬期で $20 \%$ を越える省エネルギーを達成しているが、実行度は 空調換気と情報娛楽が他の用途区分と比較して大きく、エネルギー 削減量も空調換気 (夏期 $8.2 \mathrm{MJ} /$ 日 ・冬期 $5.2 \mathrm{NJ} /$ 日) 、情報辂楽（夏 期 $1.9 \mathrm{MJ} /$ 日 ・中間期 $4.5 \mathrm{MJ} /$ 日 ・冬期 $3.2 \mathrm{MJ} /$ 日）が大きい。

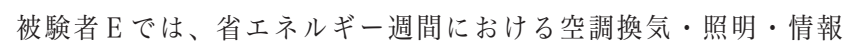
娛楽の実行度の向上が影著である。エネルギー削減量としては、夏 期の照明 ( $3.3 \mathrm{M} \mathrm{J} /$ 日) と情報娛楽 $(4.0 \mathrm{M} \mathrm{J} /$ 日)、冬期の空調換気 (9.3 M J/日) が大きい。住宅全体のエネルギー消費量が小さい被験 者 $\mathrm{F}$ では、通常週間の実行度が全項目の平均で 3 程度あり、日頃か ら省エネルギーの意識が高いと考えられる。省エネルギー週間には ほとんどの用途区分で実行度が高くなり、エネルギー削減量は情報 娛楽（冬期 $0.8 \mathrm{MJ} /$ 日・中間期 $1.0 \mathrm{MJ} /$ 日）の他、ガス（夏期 $1.9 \mathrm{MJ} /$ 日）、空調換気（中間期 $6.5 \mathrm{MJ} /$ 日）が大きい。

以上、単身世帯では、空調換気や情報娛楽に関する低負荷型ライ フスタイルの実行が全体のエネルギー消費量の削減に寄与する可能 性が高い。家事衛生については、エネルギー消費の絶対量が小さい
ため、低負荷型ライフスタイルの実行による省エネルギー効果はあ るが、全体に対する影響は小さい。表 1 中に低負荷型ライフス夕イ ルの平均実行度を示すが、空調の設定温度や使用時間、情報娛楽機 器の主電源に関わる項目で高い值が得られ、給湯に関わる項目では 低い值となった。なお、本実測は夏期・中間期 ・ 冬期の順に行って おり、例えば、図 3 の被験者 Aで、照明の平常時の実行度が夏期よ り中間期・冬期で高いように、低負荷型ライフスタイルの啓蒙によ り省エネルギー意識が向上するケースも見られた。

\section{2 家族世帯における実測}

\section{(1) 実測概要}

表 4 に、家族世帯における低負荷型ライフスタイルの省エネル ギー効果に関わる実測概要を示す。本実測は2004 年度に行われてお り、日本建築学会の住宅内のエネルギー消費に関する調査にご協力 を頂いた家族世帯の一部に、夏期・中間期・冬期それぞれ一週間の 低負荷型ライフスタイルの実行をご協力頂いたものである。実測方 法は単身世帯の場合とほぼ同じであるが、ガス・灯油についても計 器による測定を行っている。

表 4 家族世帯の実測調査概要

\begin{tabular}{|c|c|c|}
\hline 期間 & \multicolumn{2}{|c|}{ 2004年度の夏期 (8～9月) ·中間期 (6月または10月) ·冬期 (12～1月) } \\
\hline \multirow{5}{*}{ 内容 } & 電力 & 単身世帯に同じ \\
\hline & ガス & データロガーによる総消費量の5分毎の計測 \\
\hline & 灯油 & 微流量燃料油メーター、パルスロガーによる総消費量の5分毎の計測 \\
\hline & 環境 & 室内外の温湿度ロガーによる温湿度の15分毎の計測 \\
\hline & 実行度 & 単身世帯に同じ \\
\hline \multirow{3}{*}{ 被験者 } & 夏期 & $\begin{array}{l}\text { 東北(戸建6件·集合1件)、関東(戸建3件·集合1件)、北陸(戸建5件· } \\
\text { 集合1件)、関西 (戸建 } 3 \text { 件·集合1件)、九州(戸建2件·集合 } 3 \text { 件) }\end{array}$ \\
\hline & 中間期 & 北海道 (戸建 1 件)、東北 (戸建 5 件·集合 1 件)、九州 (戸建 3 件·集合 1 件 \\
\hline & 冬期 & 東北(戸建6件·集合2件)、関東(戸建2件)、北陸 (戸建2件·集合1件) \\
\hline
\end{tabular}

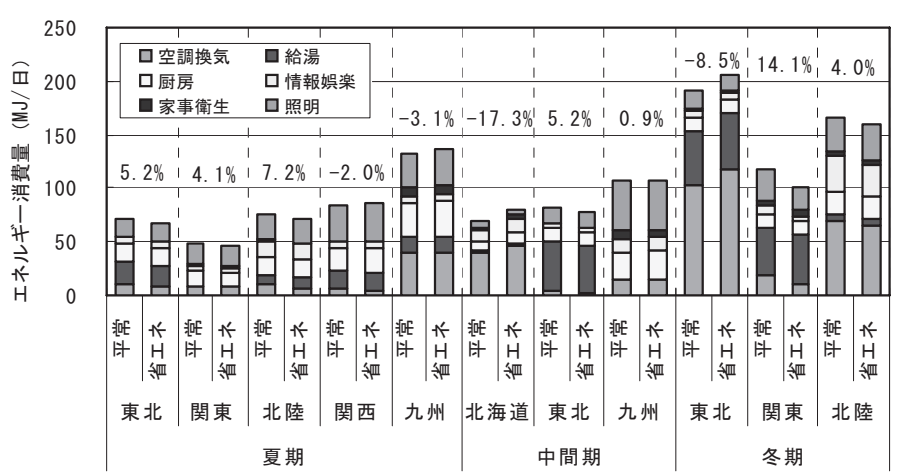

図 4 家族世帯におけるエネルギー消費量の内訳

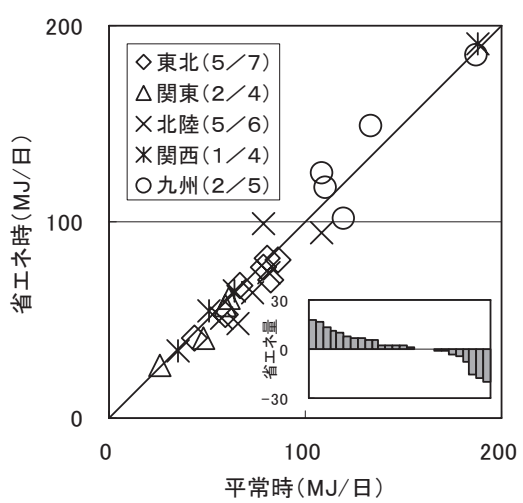

( 1 ）夏期

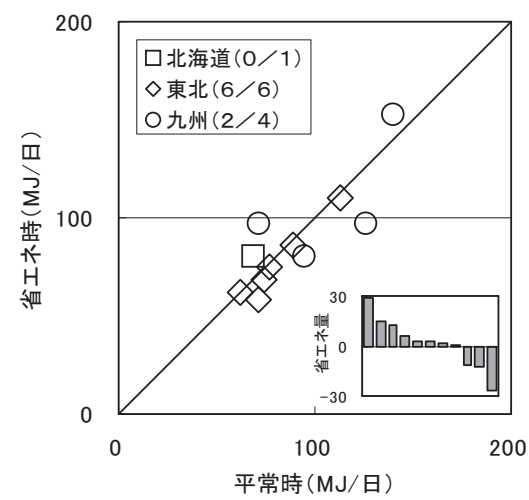

(2) 中間期

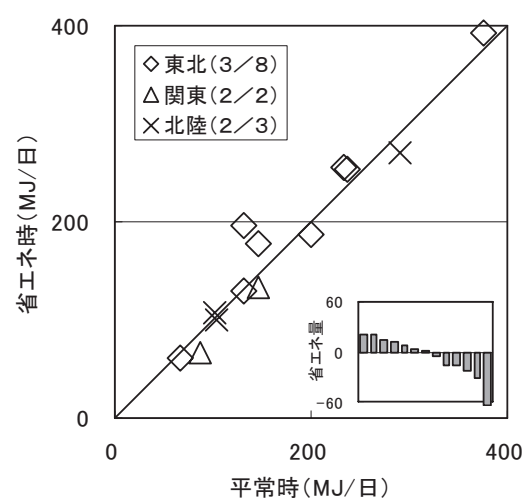

(3) 冬期

注 例えば、夏期の東北 $(5 / 7)$ は、東北 7 世帯中 5 世帯で省エネルギーが達成されたことを表わす。

図 5 各家族世帯におけるエネルギー消費量の比較 


\section{(2) 実測結果}

家族世帯における平常週間と省エネルギー週間における日平均エ ネルギー消費量の内訳を図 4 に、世帯ごとの比較を図 5 に示す。図 5 中右下の棒グラフは、省エネルギー量を降順に示したものである。 夏期について見ると、全体の 70 \%近くの住宅で省エネルギー週間に エネルギー消費の削減が達成されており、省エネルギー量の最大值 は18.1 M J/日である。地域ごとの省エネルギー率を見ると、東北・ 関東・北陸で $4.1 \sim 7.2 \%$ 、関西・九州では $-2.0 \sim-3.1 \%$ となって いる。空調のエネルギー消費量が、東北・北陸では削減されている のに対し、九州では削減されていないことが特徴的である。中間期 は被験者数が 11 件と少ないが、夏期同様 $70 \%$ 近くの住宅で削隇効果 が見られ、省エネルギー量の最大值は $28.8 \mathrm{M} \mathrm{J} /$ 日である。省エネル ギー率で $5.2 \%$ を達成した東北では、空調と給湯における削減が顕著 となっている。冬期は夏期・中間期と異なり、エネルギー消費の削 減は全体の 50 \% で見られたに留まり、省エネルギー量の最大値は $20.8 \mathrm{MJ} /$ 日である。関東で $14.1 \%$ 、北陸で $4.0 \%$ の省エネルギー率 が得られたのに対し、東北では $-8.5 \%$ となっており、空調に関わる 低負荷型ライフスタイルの実行が困難であったものと考えられる。

表 1 に示した低負荷型ライフスタイルの平均実行度を見ると、家 族世帯の場合には実行度 3.0 を超える項目が 47 項目あり、単身世帯 で実行度が低い厨房、給湯、家事衛生の低負荷型ライフスタイルも 多くの項目が実行されている。しかし、空調の「冷房（暖房）設定温 度を高くする（低くする）」や情報娛楽の「非使用時にはコンセント を抜く」のように、単身世帯よりも実行度が低い項目もあり、世帯 の各人が共通の低負荷型ライフスタイルを同時に実行することが、 省エネルギー効果を大きくするために重要と考えられる。

\section{4.まとめ}

本研究では、住宅における低負荷型ライフスタイルの実行に基づ くエネルギー消費の削減の可能性を、実住宅における実測を通じて 明らかにした。

(1) 単身世帯では、平常時のエネルギー消費量は 23.1〜 66. 4 M J/ 日で、被験者・季節による違いが大きいが、夏期・中間期・冬期の全 期間において、全被験者が $3.6 \sim 44.6 \%$ の省エネルギーを達成した。 その際、実行度の高い低負荷型ライフスタイルは、空調の設定温度・ 使用時間の調節、無䭾な照明を行わないこと、情報娛楽機器の電源 等であり、これらのエネルギー消費の削減効果が著しかった。

(2) 家族世帯では、平常時のエネルギー消費量は $26.1 \sim 376.2 \mathrm{MJ} /$ 日で、季節・地域・被験者による違いが大きいが、夏期・中間期は $70 \%$ 程度、冬期には $50 \%$ 程度の被験者が $0.9 \sim 14.1 \%$ の省エネル ギーを達成した。低負荷型ライフスタイルの実行度は全項目で比較 的高いものであったが、夏期の九州、冬期の東北の結果に示された ように、空調ではエネルギー消費の削隇が困難なケースも見られた。 今後、家族世帯の実測を重社、実生活における低負荷型ライフス タイルの活用可能性を具体化する予定である。その際、世帯各人の ライフスタイルの違いや住宅の居室環境を把握して検討を進めたい。

\section{謝辞}

本研究は、国土交通省、東京電力、関西電力、中部電力、九州電力 からの補助により設立された（社）日本建築学会「住宅内のエネル
ギー消費に関する調査研究委員会」(委員長 : 村上周三慶応義塾大学 教授）内に設置されたミクロモデル作成W G（主査：吉野 博）に て実施したものである。委員会関係者、実測にご協力頂いた方々に 感謝の意を表します。

\section{参考文献}

1) 平成 18 年度エネルギーに関する年次報告（エネルギー白書 2007）

2) 長谷川善明、井上 隆：全国規模アンケートによる住宅内エネルギー消費 の実態に関する研究 世帯特性の影響と世帯間のばらつきに関する考察 そ の 1、日本建築学会環境系論文集、N0.583、pp. $23 \sim 28 、 2004.9$

3) 山岸明浩、赤林伸一、坂口 淳、浅間英樹、石山洋平 : 用途別エネルギー消 費量の実態 新潟地域の住宅におけるエネルギー消費に関する調査研究 そ の1、日本建築学会環境系論文集、N0.593、pp. 25～31、2005.7

4) 伊香賀俊治、三浦秀一、外岡 豊、下田吉之、小池万里、深澤大樹、水石 仁 : 住宅のエネルギー消費量と $\mathrm{CO}_{2}$ 排出量の都道府県別マクロシミュレーション 手法の開発、日本建築学会技術報告集、N0.22、pp. 263 268、2005. 12

5) 村上周三、赤林伸一、絵内正道、吉野 博、飯尾昭彦、坊垣和明、鉾井修一、 渡辺俊行、坂口 淳 : 住宅を対象としたエネルギー消費量の測定システムの 開発研究、日本建築学会技術報告集、N0.22、pp. 355 358、2005. 12

6) 村上周三、坊垣和明、田中俊彦、羽山広文、吉野 博、赤林伸一、井上隆、 飯尾昭彦、鉾井修一、尾崎明仁、石山洋平 : 全国の住宅 80 戸を対象とした エネルギー消費量の長期詳細調査、対象住宅の属性と用途別エネルギー消費 量、日本建築学会環境系論文集、N0.603、pp.93～100、2006.5

7) 吉野 博、村上周三、赤林伸一、坊垣和明、田中俊彦、羽山広文、尾崎明仁、 菅原華子 : 住宅のピーク電力に関する調査研究 住宅エネルギー消費実態の 全国調査デー夕に基づく分析、日本建築学会環境系論文集、N0.610、pp.99 $\sim 106 、 2006.12$

8) 赤林伸一、水谷国男、高倉秀一、須山善美、桑原亮：気候特性に対応した住 宅の断熱・気密性能に関する検討 住宅の換気・通風に関する実験的検討 その $2 、$ 日本建築学会計画系論文集、N0.464、pp. $47 \sim 56 、 1994.10$

9) 長谷川兼一、吉野 博、松本真一: 東北地方に抢ける断熱気密住宅のエネル ギー消費量一暖房用を中心とした実態調査と数値計算一、日本建築学会計画 系論文集、N0.557、pp.49〜56、2002.7

10 ) 森 教子、森山正和、漆原 慎：エネルギー供給形態の異なる戸建住宅の エネルギー消費量と節約行為による省エネルギー効果に関する研究、日本建 築学会計画系論文集、N0.565、pp.99〜106、2003.3

11 ) 前 真之、鍋島美奈子、鎌田元康 : 生活時間のパ夕ーン分類 都心部集合 住宅居住者のライフスタイルとエネルギー消費に関する研究 その 1、日本 建築学会環境系論文集、N0.573、pp. 103〜 109、2003.11

12 ) 澤島智明、松原斎樹、藏澄美仁 : 防暑行為の実施実態と居住者の意識・価 值観 プレハブ住宅居住者の夏期の防暑行為に関する研究 その 1 、日本建 築学会環境系論文集、No. 578、pp.9〜 15、2004.4

13 ) 丹羽悠介、中谷洋一、岩井一博、山下恭弘：長野県の戸建住宅における暖 房用エネルギー消費量一居住者意識及び暖房の仕方からみた検討一、日本建 築学会環境系論文集、No. 581、pp. 73〜 79、2004. 7

14 ) 大和義昭、松原斎樹、藏澄美仁：京都市および近郊の住宅におけるエネル ギー消費量と居住者の意識・住まい方に関する調査研究、日本建築学会環境 系論文集、No.586、pp. 17〜 23、2004. 12

15 ) 平松義久、浅森智子、垂水弘夫 : 家族成長を考慮した住宅エネルギーシス テムの評価、日本建築学会環境系論文集、N0.594、pp. 45～52、2005. 8

16) 水谷 傑、井上 隆、小熊孝典: 住宅内に打る用途別エネルギー消費と住 まい方の実態に関する研究ーアンケート調査に基づく分析一、日本建築学会 環境系論文集、No. 609、pp. $117 \sim 124 、 2006.11$

17 ) 小林恵美子、松原斎樹、蔵澄美仁、飛田国人 : 京都市の集合住宅居住者の 意識・住まい方とエネルギー消費量に関する研究、日本建築学会技術報告 集、N0.24、pp. 241 244、2006. 12

18 ) 長谷川兼一、吉野 博、湯浅和博、千葉智成、室 恵子、石田建一、三田 村輝章、村上周三 : 低負荷型ライフスタイルの省エネルギー効果 : 標準型住 宅モデルを用いた数値計算による検討、日本建築学会環境系論文集、 No. 608、pp. $97 \sim 104 、 2006.10$

$19)$ 湯淺和博、他：ライフスタイルからみた住宅のエネルギー消費に関する研 究、日本建築学会大会学術講演梗概集、D2、pp.385 390、2004 